\title{
Polyphyly of true branching cyanobacteria (Stigonematales)
}

Correspondence

Lucien Hoffmann

hoffmann@crpgl.lu

\author{
Muriel F. Gugger and Lucien Hoffmann \\ Public Research Centre - Gabriel Lippmann, Environment and Biotechnologies Research Unit, \\ 162A, avenue de la Faïencerie, L-1511 Luxembourg
}

\begin{abstract}
Cyanobacteria with true branching are classified in Subsection V (formerly order Stigonematales) in the phylum Cyanobacteria. They exhibit a high degree of morphological complexity and are known from particular biotopes. Only a few stigonematalean morphotypes have been cultured, and therefore the high variability of morphotypes found in nature is under-represented in culture. Axenic cultures of Chlorogloeopsis and Fischerella sensu Rippka et al. were, to date, the only representatives of this Subsection in phylogenetic studies. The 16S rDNA sequence analysis data in this report confirm that heterocyst-forming cyanobacteria are a monophyletic group. However, unlike previous studies have suggested, these $16 \mathrm{~S}$ rDNA data on new Stigonematales strains show that the true branching cyanobacteria are polyphyletic and can be separated into at least two major groups defined by their branching type, the first group being characterized by T-branching and the second group by Y-branching. Cyanobacteria with intercalary heterocysts and either no branching or false-branching also formed separate clusters. In consequence, our phylogenetic data do not correlate with the bacteriological and traditional classifications, which distinguish filamentous heterocystous cyanobacteria with or without true branching (Nostocales/Stigonematales).
\end{abstract}

\section{INTRODUCTION}

Heterocyst-differentiating cyanobacteria correspond to a monophyletic lineage (Giovannoni et al., 1988; Wilmotte \& Herdman, 2001) in which two subgroups are traditionally distinguished. The first subgroup consists of filamentous heterocystous cyanobacteria dividing always in a plane at right angles to the long axis of the trichome and therefore uniseriate and lacking true branchings. They are grouped in Subsection IV according to the proposed bacteriological classification (Rippka et al., 1979; Castenholz, 2001) and in the order Nostocales in the traditional classification system (Komárek \& Anagnostidis, 1989). The second subgroup consists of filamentous heterocystous cyanobacteria in which longitudinal and oblique cell divisions occur in addition to transverse cell divisions resulting in periodic true branching in all genera and in multiseriate trichomes (two or more rows of cells) in some genera. They are classified in Subsection V (formerly order Stigonematales) (Rippka et al., 1979; Anagnostidis \& Komárek, 1990; Castenholz, 2001).

The thallus of the Stigonematales is generally composed of a main creeping axis and secondary erect branches. In some

Published online ahead of print on 8 August 2003 as DOI 10.1099/ ijs.0.02744-0.

The GenBank accession numbers for the cyanobacterial 16S rDNA sequences are AJ544076-AJ544090 and AJ544222. taxa, a heterotrichous thallus formed by a noticeable difference in the shape and dimensions of the cells of the main axis and the secondary branches may occur. True branching cyanobacteria, characterized by the presence of branchpoint cells in contact with three different neighbouring cells, exhibit the highest degree of morphological complexity and differentiation within the cyanobacteria. Three major types of true branchings, named ' $\mathrm{T}$ ', ' $\mathrm{V}$ ' and ' $\mathrm{Y}$ ', can be distinguished (for a review, see Golubíc et al., 1996). T-branching is formed by a lateral, nearly perpendicular branching originating by the change of division plane from transverse to longitudinal. V-branching consists of a dichotomous or pseudodichotomous bifurcation originating from a change in division plane at, or close to, the trichome tip. Y-branching arises from the displacement of an intercalary branch-point cell by meristematic growth around it. False-branching also occurs in some genera. Moreover, the position of the heterocysts varies from terminal to lateral (sessile or pedicellate) and intercalary (see Table 2 in Anagnostidis \& Komárek, 1990). Multiplication arises from trichome breakage, hormogonia, hormocysts, akinetes or akinete-like cells, depending on the genus. Based on these morphological criteria, Anagnostidis \& Komárek (1990) reorganized the order at the family level and recognized eight families with 48 genera.

The most frequently represented Stigonematales in culture are the genera Fischerella (Born. et Flah.) Gom. 1895, 
Hapalosiphon Näg. in Kütz. ex Born. et Flah. 1886 and Mastigocladus Cohn ex Kirchner 1898. However, a large number of poorly studied stigonematalean cyanobacteria are known from freshwater and subaerial biotopes, such as slightly acidic, oligotrophic lakes or caves. Only two genera have been characterized from axenic culture strains, Fischerella (incl. Mastigocladus and Hapalosiphon) and Chlorogloeopsis Mitra et Pandey 1966 (Rippka et al., 1979; Herdman et al., 1979a, b; Lachance, 1981). Because of the few true branching cyanobacteria studied according to bacteriological standards, only six genera were included in Subsection V of Bergey's Manual of Systematic Bacteriology (Hoffmann \& Castenholz, 2001).

The analysis of the few available $16 \mathrm{~S}$ rDNA sequences revealed that true branching cyanobacteria form a monophyletic group arising from an assemblage of filamentous heterocystous cyanobacteria without branching (Giovannoni et al., 1988; Hoffmann \& Castenholz, 2001; Fewer et al., 2002; Litvaitis, 2002). In this study, 16 strains allocated to the genera of Fischerella, Hapalosiphon, Mastigocladopsis Iyeng. et Desik. 1946, Nostochopsis Wood ex Born. et Flah. 1886, Stigonema Ag. ex Born. et Flah. 1886 (reference genus of the Stigonematales), Symphyonema Jao 1944, Symhyonemopsis Tiwari et Mitra 1969 and Westiellopsis Janet 1941 were examined morphologically and genotypically to extend the range of morphotypes represented in phylogenetic trees. In particular, isolates differing by their branching types (Y-vs T-branching) and the position of the heterocysts (intercalary, lateral-sessile, lateral-pedicellate) were represented. The genetic relationship within the true branching cyanobacteria and with the other heterocystous cyanobacteria was inferred by the analysis of 16S rRNA gene sequences.

\section{METHODS}

Organisms and growth conditions. A list of branched filamentous heterocystous cyanobacteria used in this study is given in Table 1. Strains 1711, 804-1, 89-45, 1269-1, 1517, VAPOR1, 1590-1, 1590-2, 985-1 and 89-785/4 were isolated from material collected in Papua New Guinea, Corsica and Spain, and identified to the genus level according to algological literature (Table 2). Strains SAG 16.93, SAG 20.27 (=BB98.1), SAG 23.96 and SAG 48.90 were purchased from Sammlung von Algenkulturen at the University of Göttingen, Germany, and strains PCC 6718 and PCC 7414 were obtained from the Institut Pasteur, Paris, France. Nostochopsis lobatus BB92.1 (=SAG 2.97) was received from B. Büdel (University of Kaiserslautern, Germany) and the Mastigocladopsis repens MORA type strain was from M. Hernandez-Mariné (University of Barcelona, Spain). Clonal,

Table 1. Branched filamentous heterocystous cyanobacteria used in this study

\begin{tabular}{|c|c|c|c|}
\hline Taxon & Strain ${ }^{\star}$ & Origin/date & References $\dagger$ \\
\hline Chlorogloeopsis sp. & PCC 7518 & Hot spring, Iceland/1968 & $1,2,6$ \\
\hline Fischerella sp. & 1711 & Soil, Papua New Guinea/1986 & This work \\
\hline Fischerella sp. & SAG 20.27 & Rice field, India/? & 11 , this work \\
\hline Hapalosiphon welwitschii & & Soil, Australia/? & 13 \\
\hline Mastigocladopsis repens & MORA & Soil, Punta de la Mora, Tarragona, Spain/1991 & 5,8 \\
\hline Nostochopsis lobatus & BB92.1 & Cryptoendolithic in sandstone, freshwater, South Africa/1990 & 9 \\
\hline Nostochopsis sp. 'Mastigocladopsis jogensis' & $89-45$ & On submerged stone in freshwater, Corsica, France/1989 & 4,7 \\
\hline Stigonema ocellatum & SAG 48.90 & Sphagnum bog, Allgäu, Germany/1970 & This work \\
\hline Symphyonema sp. & $1269-1$ & Soil, Papua New Guinea/1986 & This work \\
\hline Westiellopsis sp. & $1590-1$ & Soil, Papua New Guinea/1986 & This work \\
\hline Westiellopsis sp. & $1590-2$ & Soil, Papua New Guinea/1986 & This work \\
\hline Westiellopsis sp. & $985-1$ & Soil, Papua New Guinea/1986 & This work \\
\hline Westiellopsis sp. & $89-785 / 4$ & Soil, Papua New Guinea/1989 & This work \\
\hline
\end{tabular}

${ }^{\star}$ PCC, Institut Pasteur, Paris, France; SAG, Sammlung von Algenkulturen Universität Göttingen, Germany. Other strains are maintained at the Culture Collection of Micro-organisms held at the Environment and Biotechnologies Research Unit of the Public Research Centre - Gabriel Lippmann, Luxembourg. Strains not available for morphological observation are highlighted in bold.

$\nmid$ †eferences: 1, Castenholz (1969); 2, Castenholz (1978); 3, Rippka et al. (1979); 4, Hoffmann (1990); 5, Hernandez-Mariné et al. (1992); 6, Wilmotte et al. (1993); 7, Hoffmann (1994); 8, Merino et al. (1994); 9, Weber et al. (1996); 10, Turner et al. (1999); 11, Fewer et al. (2002); 12, Hoffmann et al. (2003); 13, D. Hoffmann \& D. L. Troelstrup (unpublished). 
Table 2. Observation of diacritical morphological features used for the classification of the Stigonematales

Morphological observation made on 18 cultures and one unavailable culture (in bold). The latter was based on previously published photomicrographs (Hoffmann \& Castenholz, 2001). For each culture, the types of thallus, branching (Irr, irregular; NO, never observed; T, T-branching; Y, Y-branching; FB, false-branching) and multiplication (HG, hormogonia; HY, hormocysts; A, akinetes) are described. In addition, heterotrichy that indicates differences in the shape of the cells of the main and secondary branches $[+$, clear differences; $(+)$ small differences, -, no difference; NA, criteria not applicable; U, uniseriate; B, biseriate; M, multiseriate] and the heterocyst position (Tr, terminal; I, intercalary; LS, lateral-sessile; LP, lateral-pedicellate; parentheses indicate infrequent occurrence) are indicated.

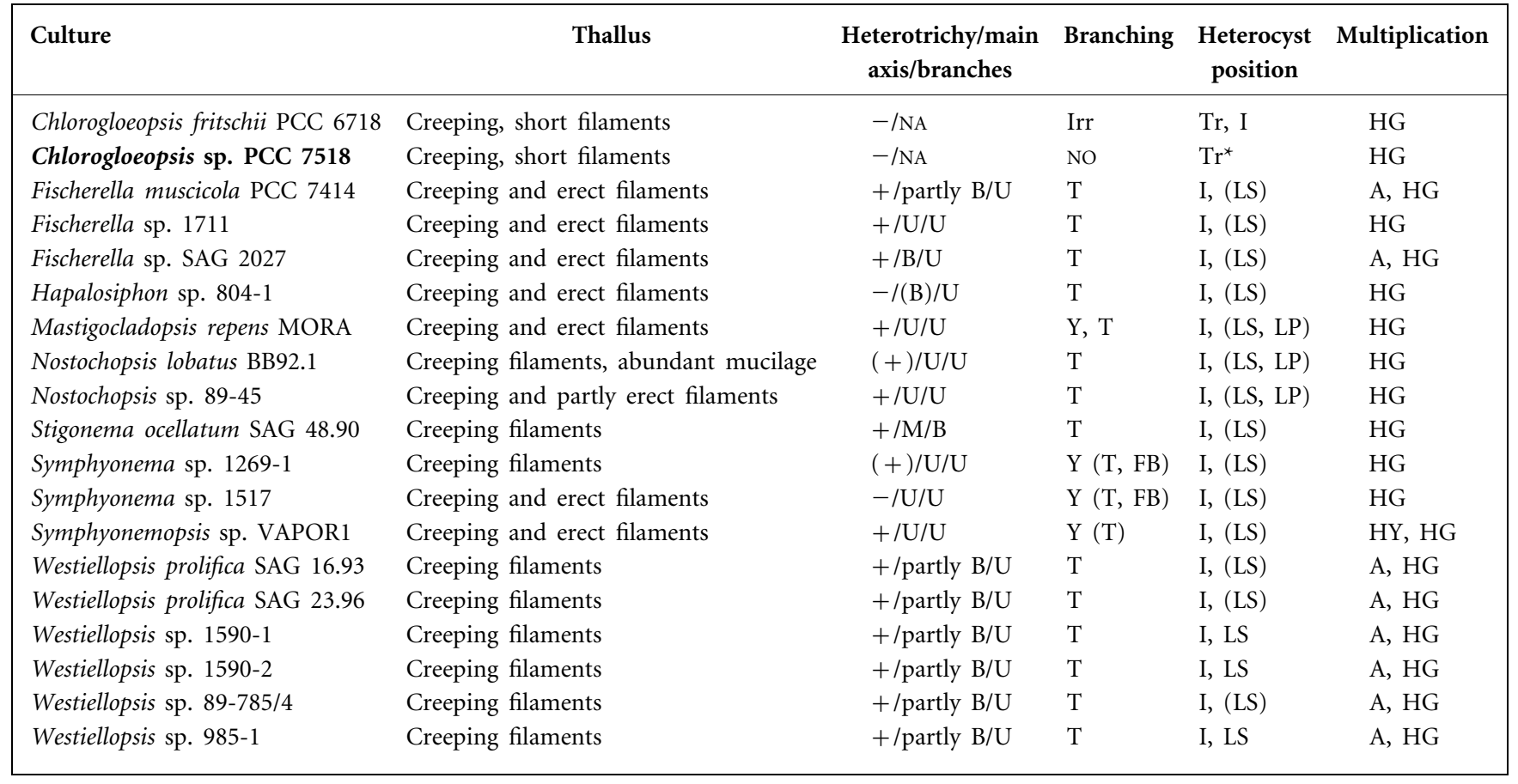

${ }^{\star}$ Heterocyst differentiation lost in some subcultures (Wilmotte et al., 1993).

uni-cyanobacterial cultures were maintained in BG11 (Rippka et al., 1979) or Z8 media (Kotai, 1972) without nitrogen at a constant temperature $\left(20^{\circ} \mathrm{C}\right)$ and continuous light $\left(20 \mu \mathrm{mol}\right.$ quanta $\left.\mathrm{m}^{-2} \mathrm{~s}^{-1}\right)$.

Morphology. Morphological observations were made on 2-weekold and 2-month-old cultures, in liquid as well as on solid media. Microphotographs from the strains were taken using a Leica DC 500 video camera with a Leica DMR light microscope. The pictures were then processed with Image Pro Plus. Thallus growth, filament structure, types of branching, position of the heterocysts and multiplication were recorded.

Oligonucleotide primers. $16 \mathrm{~S}$ rDNA was amplified and sequenced using the eubacterial primer $8 \mathrm{~F}$ (Lane, 1991) combined with two reverse primers, the heterocystous cyanobacteria-specific primer 1480 (Gugger et al., 2002) and primer 1380R (5'-TAACGACTTCGGGCGTGACC- $3^{\prime}$ ) designed in this study. To retrieve the complete sequence in both strands, forward primer 861 (Gugger et al., 2002) and reverse primers 450R (5'-CTGCTGGCACGGAGTTAGC$\left.3^{\prime}\right)$ and 920R (5'-TTGTAAGGTTCTTCGCGTTG-3') were used.

PCR amplification. PCR amplification of $16 \mathrm{~S}$ rDNA was performed in a volume of $50 \mu \mathrm{l}$ containing $2 \mu \mathrm{l}$ culture, $200 \mu \mathrm{M}$ dNTP, $20 \mu \mathrm{M}$ each primer and $5 \mu 110 \times$ LA PCR buffer II (TaKaRa). This template was three times alternatively frozen in liquid nitrogen and boiled prior to the addition of $2.5 \mathrm{U}$ TaKaRa LA Taq polymerase. The thermal cycling conditions were $4 \mathrm{~min}$ denaturation at $95^{\circ} \mathrm{C}$,
35 cycles of $30 \mathrm{~s}$ denaturation at $93{ }^{\circ} \mathrm{C}, 30 \mathrm{~s}$ annealing at $50{ }^{\circ} \mathrm{C}$ and $30 \mathrm{~s}$ extension at $72{ }^{\circ} \mathrm{C}$, followed by a $7 \mathrm{~min}$ elongation at $72^{\circ} \mathrm{C}$. The concentration of the amplified products was checked on $1 \%$ agarose gel and purified with the Wizard PCR Preps DNA Purification System (Promega).

Sequencing. The PCR products of $16 \mathrm{~S}$ rDNA were sequenced directly. DNA sequencing was performed with the ABI PRISM Big Dye Terminator Cycle Sequencing Ready Reaction Kit and the ABI PRISM 310 Genetic Analyser (Perkin Elmer) according to the manufacturer's instructions. The sequenced fragments were assembled into contigs using GeneDoc version 2.6.002 (www.psc.edu/ biomed/genedoc/). The sequences were obtained for both strands independently.

Phylogenetic trees. The sequences were aligned and edited for manual correction using GeneDoc version 2.6.002. Phylogenetic trees were constructed using the neighbour-joining method on Jukes \& Cantor (1969) and the Wagner parsimony method of PHYLIP version 3.5c (Felsenstein, 1993). The outgroup was constituted either by distantly related cyanobacteria belonging to Microcystis and Planktothrix (Otsuka et al., 1998; Lyra et al., 2001; Suda et al., 2002) or by the paralogous group of Chroococcidiopsis, as defined by Fewer et al. (2002). Bootstrap analysis of 500 resamplings was performed for each consensus tree. Only the bootstrap values above $80 \%$ are indicated at the nodes of the trees. The trees were edited using TREEVIEW version 1.6.1 (Page, 1996). 


\section{RESULTS AND DISCUSSION}

\section{Morphological features of true branching cyanobacteria}

Eight morphotypes corresponding to the genera Fischerella, Hapalosiphon, Mastigocladopsis, Nostochopsis, Stigonema, Symphyonema, Symphyonemopsis and Westiellopsis were distinguished among the studied culture strains (Fig. 1; Table 2). On solid medium, all the stigonematalean isolates had a creeping growth. Old cultures of Fischerella sp. 1711 and SAG 20.27, Nostochopsis sp. 89-45, Mastigocladopsis repens MORA, Symphyonema sp. 1517 and Symphyonemopsis sp. VAPOR1 also developed erect filaments on solid medium.
The heterotrichous filament morphology (Fig. 1a, b, c; Table 2) was conspicuous for Fischerella sp. 1711, PCC 7414 and SAG 20.27, Nostochopsis sp. 89-45, Mastigocladopsis repens MORA, Stigonema ocellatum SAG 48.90, Symphyonemopsis sp. VAPOR1, Westiellopsis prolifica SAG 16.93 and SAG 23.96, and Westiellopsis sp. 1590-1, 1590-2, 985-1 and 89-785/4. Heterotrichy was faint in Nostochopsis lobatus BB92.1 (Fig. 1f, g) and Symphyonema sp. 1269-1, and absent in old cultures of Hapalosiphon sp. 804-1 and Symphyonema sp. 1517 (Fig. 1e) and in two Chlorogloeopsis strains, PCC 6718 and PCC 7518. The two latter strains formed irregular or no branches. The main axis was uniseriate to biseriate in all strains (Fig. 1d) and multiseriate in Stigonema ocellatum SAG 48.90 (Fig. 1b).

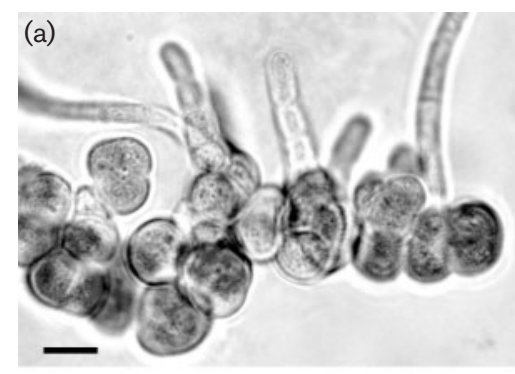

(b)
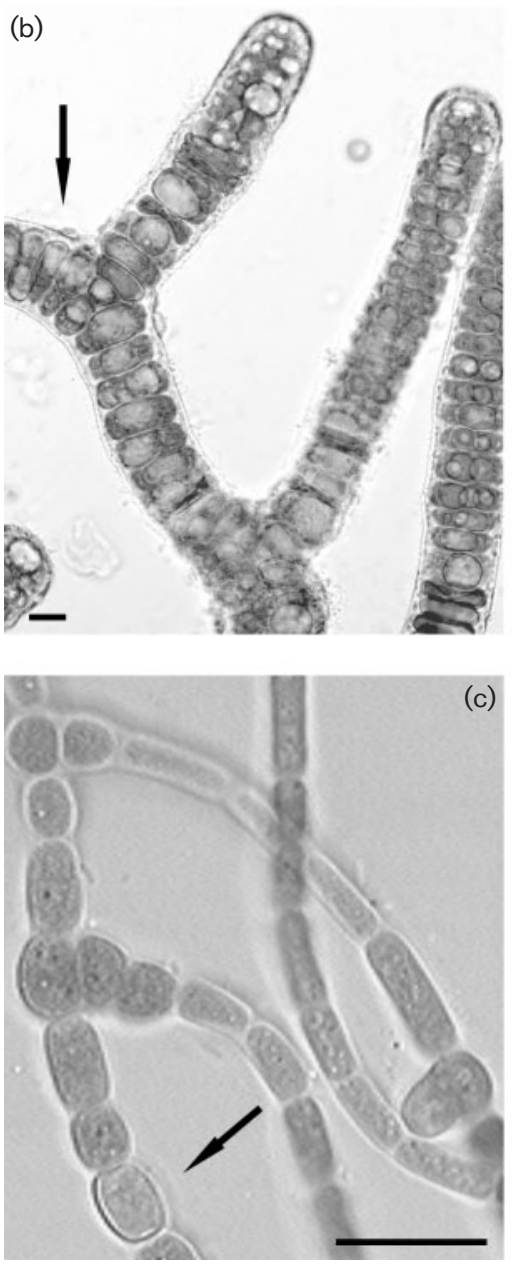
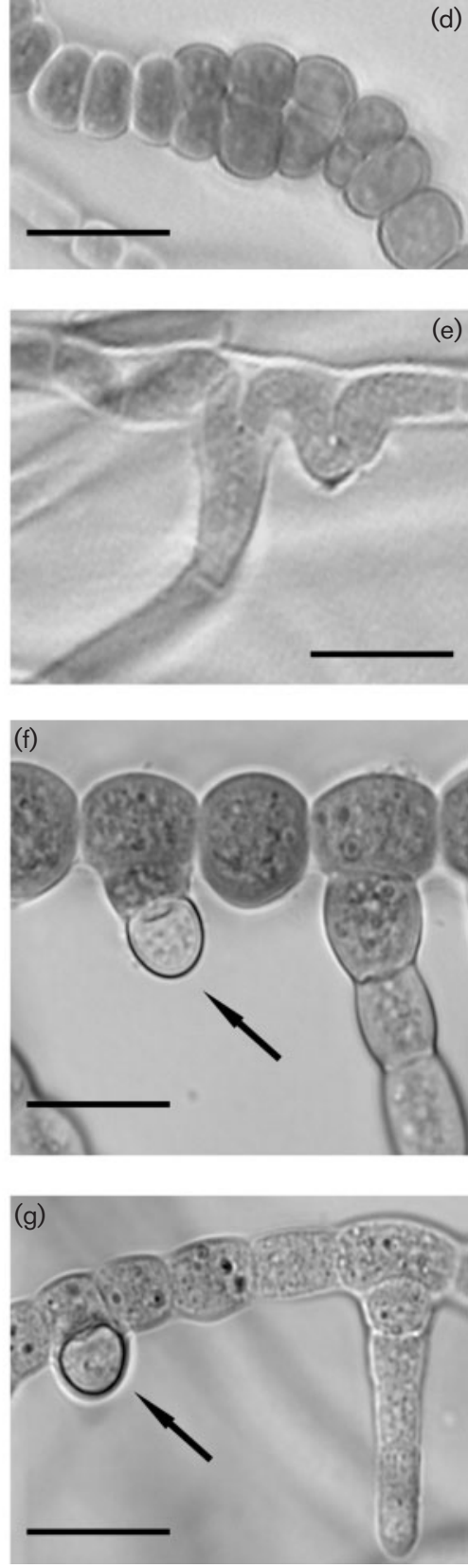

Fig. 1. Photomicrographs of diacritical criteria used in the traditional classification of the Stigonematales. (a) Heterotrichy and young T-branches of Fischerella sp. SAG 20.27; (b) multiseriate T-branches of Stigonema ocellatum SAG 48.90; (c) Heterotrichy and T-branch formation by lateral protuberance in Westiellopsis sp. 1590-1; (d) partly biseriate main axis in Westiellopsis prolifica SAG 23.96; (e) Y-branching formation in Symphyonema sp. 1517; (f) lateral pedicellate heterocyst and mature T-branch in Nostochopsis lobatus BB92.1; (g) lateral sessile heterocyst and T-branch formation by lens-shaped septation in Nostochopsis lobatus BB92.1. Heterocysts are indicated by arrows. Bars, $10 \mu \mathrm{m}$. 
Mastigocladopsis repens MORA, Symphyonemopsis sp. VAPOR1 and Symphyonema sp. 1269-1 and 1517 exhibited branches of the Y-type (Fig. 1e), some T-type branches as well as false branches in the two latter isolates. In these four strains, the Y-type branch was initiated by the oblique division of an intercalary cell in a straight portion of the trichome. The resulting branch-point cell became subsequently displaced by elongation or by division of the meristem [respectively observed in Symphyonema sp. 1517 in Fig. 1(e) and Mastigocladopsis repens MORA].

The 13 remaining strains only formed branches of the T-type (Fig. 1a, b, c, f, g; Table 2). Most of them developed T-branches through three different initial stages: (1) change in division plane by longitudinal septation immediately following a transversal division, (2) branch formation starting with a lateral protuberance or bulge, which is subsequently cut off by longitudinal septation (Fig. 1c), or (3) branch formation starting with lens-shaped septation conspicuous in Nostochopsis lobatus BB92.1 (Fig. 1g) and Nostochopsis sp. 89-45. In the culture of the latter strain, some Y-type like branches were also observed scarcely. In the description of the field material, this sample was assigned to Mastigocladopsis jogensis (Hoffmann, 1990), but the morphological observation of the culture revealed that the ontogeny of branch formation in the isolated strain 89-45 differed from that in the four Y-branching strains. The branches in Nostochopsis sp. 89-45 were initiated by typical T-branches. The new branch-point cell elongated, whereas a one-sided cleavage from the opposite side of the T-branch appeared. The cleavage of the cell remained incomplete, leading to a Y-shaped branch-point cell. Although the final appearance of the branch was Y-shaped, its origin is of the T-type.

Except for the two Chlorogloeopsis strains, the heterocysts in the stigonematalean isolates were mainly intercalary and less frequently lateral (Fig. 1 b, c, f, g; Table 2). Whereas lateral-sessile heterocysts (Fig. 1g) were observed in almost all strains, at least occasionally, lateral-pedicellate heterocysts (Fig. 1f) were only observed in Nostochopsis lobatus BB92.1 and 89-45, and in Mastigocladopsis repens MORA. The multiplication strategy of the isolates was mainly by hormogonia, but concomitantly, Symphyonemopsis sp. VAPOR 1 adopted the differentiation of hormocysts and most of the strains of Fischerella and Westiellopsis produced akinetes or akinete-like cells.

\section{Primer design}

The amplification of the 16S rDNA of the Stigonematales by using the combination of a universal primer and heterocystous-cyanobacteria-specific primer 1480 resulted in poor amplification of the locus from certain strains. The recognition site of primer 1480 is located near a polymorphic region. This region was longer in the $16 \mathrm{~S}$ rDNA sequence of the Stigonematales compared to that of the Nostocales and thus overlapped the recognition site of the reverse primer. The presence of this polymorphism in the $3^{\prime}$ end of the reverse primer resulted in uneven amplification. Therefore, a new reverse primer, 1380R, hybridizing to the conserved region forward of the polymorphic site was used to retrieve $16 \mathrm{~S}$ rDNA amplicons. Primer $1380 \mathrm{R}$ is specific to the Cyanobacteria, but not to heterocystous cyanobacteria and therefore must be used on uni-cyanobacterial or axenic cultures.

\section{Comparison of the 16S rRNA gene sequences of the Stigonematales}

The 16 stigonematalean $16 \mathrm{~S}$ rDNA (1239-1488 bp) sequences obtained were compared to the five Stigonematales sequences available in GenBank. 16S rDNA sequences from the true-branching cyanobacteria shared $89 \%$ or more similarity. Surprisingly, the sequence of Fischerella sp. SAG 20.27 from GenBank (AJ344560; Fewer et al., 2002) differed in several sites from the sequence obtained in this study from the purchased strain Fischerella sp. SAG 20.27. The divergence between two 16S rDNA sequences from this strain ( $96.6 \%$ sequence similarity) is high enough to be considered as two taxonomic units. On the other hand, the sequences of Fischerella sp. SAG 20.27 from GenBank and of Nostochopsis lobatus BB92.1 were identical. It has already been demonstrated that some cyanobacteria contained multiple ribosomal operons (Iteman et al., 2002). However, if strain SAG 20.27 possessed two copies, both of them would be amplified. As Fischerella sp. SAG 20.27 (=BB98.1) and Nostochopsis lobatus BB92.1 (=SAG 2.97) were both isolated by B. Büdel and deposited in the SAG collection, a possible confusion could explain that the sequence of Fischerella sp. SAG 20.27 deposited in GenBank (AJ344560) corresponds to the sequence of Nostochopsis lobatus BB92.1.

The sequences of Nostochopsis lobatus BB92.1 (and SAG 20.27 from GenBank) and Nostochopsis sp. 89-45 differed from that of other Stigonematales by a polymorphic locus of $14 \mathrm{nt}$ contiguous to an insertion of $17 \mathrm{nt}$ in the $5^{\prime}$ end of the 16S rRNA gene, and differed from each other by five positions in this polymorphic locus (Fig. 2). This $31 \mathrm{nt}$ region was positioned within helix 6 of the secondary structure model for the 16S rDNA of Chlorogloeopsis sp. PCC 7518 (Wilmotte et al., 1993) and may represent a sequence signature for the Nostochopsis strains (Fig. 2).

\section{Phylogenetic relationships of true branching cyanobacteria in the 165 rRNA gene tree}

To discuss the phylogenetic position of true branching cyanobacteria within the cyanobacterial radiation, the $16 \mathrm{~S}$ rDNA sequences available for the Stigonematales were compared with those of well identified heterocystous cyanobacteria lacking true branching (Subsection IV, Nostocales), i.e. strains of the genera Anabaena, Aphanizomenon, Cylindrospermopsis, Nodularia, Nostoc and Scytonema. The topologies of the trees were similar using as outgroup either distantly related cyanobacteria or the paralogous Chroococcidiopsis cluster. Moreover, the distance 


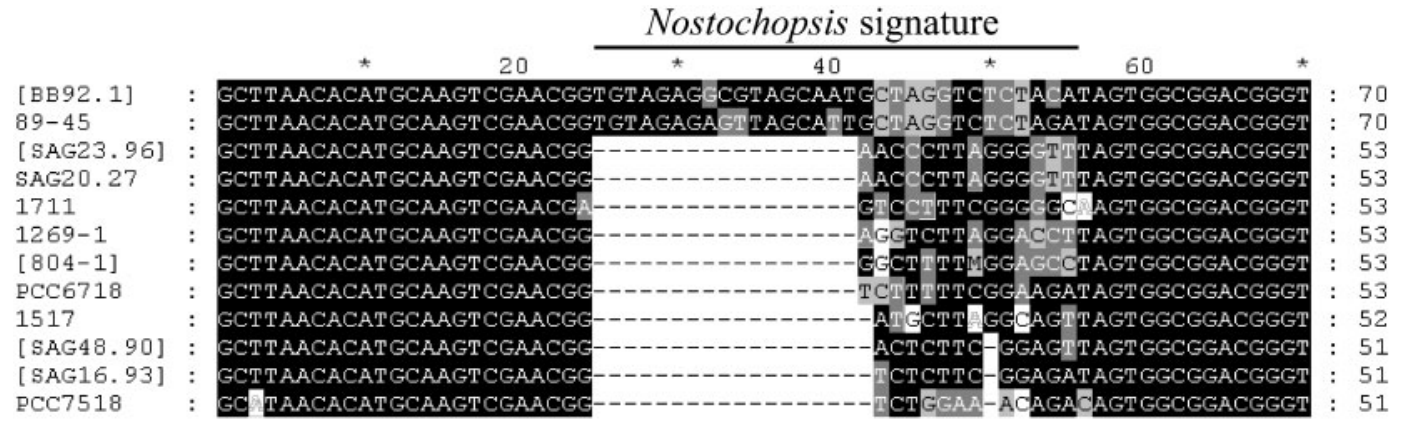

Fig. 2. Sequence signature of Nostochopsis strains in the $5^{\prime}$ end of the $16 \mathrm{~S}$ rRNA gene. Strains in brackets are representatives of strains showing identical sequences: [BB92.1] represents the sequences of BB92.1 and SAG 20.27 (AJ344560); [SAG 23.96] represents SAG 23.96, 89-785/4, 985-1, 1590-1, 1590-2 and SAG 20.27 (this study); [804-1] represents 804-1 and PCC 7414 (AJ132788); [SAG 48.90] represents SAG 48.90 and VAPOR1; [SAG 16.93] represents SAG 16.93 and Hapalosiphon welwitschii (AY034793).

and parsimony trees were congruent. Thus, only the distance tree for the phylogenetic relationships of the Stigonematales with other heterocystous cyanobacteria is presented (Fig. 3).

The group of Stigonematales strains was polyphyletic and separated into four clusters (1, 2, 3 and 5 in Fig. 3 ) and one separate branch (Stigonema ocellatum SAG 48.90). Cluster 1, highly supported by bootstrap values (100/97\%), revealed a tight grouping of T-branching genera. It divided into a single branch with Fischerella sp. 1711 and three subclusters, 1a-1c, each highly supported by bootstrap values. Cluster la contained the identical sequences of Westiellopsis prolifica SAG 23.96, Westiellopsis sp. 89-785/4, 985-1, 1590-1 and 1590-2, and Fischerella sp. SAG 20.27 (this study). Cluster $1 \mathrm{~b}$ comprised the closely related sequences of Westiellopsis prolifica SAG 16.93 and Hapalosiphon welwitschii ( $98 \cdot 8 \%$ sequence similarity). Cluster 1c contained the identical sequences of Nostochopsis lobatus BB92.1 and Fischerella sp. SAG 20.27 from GenBank, and the sequence of Nostochopsis sp. 89-45 (97.2\% sequence similarity). According to their high sequence similarity, the strains of Fischerella, Hapalosiphon and Westiellopsis in cluster 1a and 1b are conspecific (Stackebrandt \& Goebel, 1994). Moreover, the high variability in morphological characters has already been revealed in Westiellopsis (JeejiBai, 1972), suggesting the need for a revision of the genera Fischerella, Hapalosiphon and Westiellopsis. The Nostochopsis strains of cluster 1c were distinguished phylogenetically and morphologically from strains of clusters $1 \mathrm{a}$ and $1 \mathrm{~b}$ by their sequence signature, the presence of lateral-pedicellate heterocysts and by a frequent asymmetrical lens-shaped septation of the branch-point cell. Following the classification system of Anagnostidis \& Komárek (1990), the strains of cluster 1 are classified into three families (Fischerellaceae, Mastigocladaceae and Nostochopsaceae). This level of classification is not consistent with our sequence data. According to the criterion used for genus definition (95\% $16 \mathrm{~S}$ rDNA sequence similarity) of Ludwig et al. (1998), the strains of cluster 1 would belong to a single genus.

Clusters 2 and 3 were always basal to cluster 1 (Fig. 3). Cluster 2, highly sustained by bootstrap values (100/97\%), comprised Fischerella muscicola PCC 7414 and Hapalosiphon sp. 804-1, sharing $95 \%$ sequence similarity. Cluster 3 contained the Chlorogloeopsis sp. strains PCC 6718 and PCC 7518 , sharing only $91 \%$ sequence similarity. The two Chlorogloeopsis strains differed by having irregular or no branching and were the most distantly related to the other branching cyanobacteria ( $89 \%$ similarity sequence). Moreover, phylogenetic studies based on nifH (Zehr et al., 1997) and 16S rRNA genes (Wilmotte et al., 1993) of several Chlorogloeopsis isolates suggested that this morphotype probably represents several distinct genera (Wilmotte, 1994). The validity of clusters 2 and 3 must be regarded with caution as they contained long internal branches and low sequence similarities.

Cluster 5 contained the four Y-branching stigonematalean strains Symphyonemopsis sp. VAPOR1, Mastigocladopsis repens MORA and Symphyonema sp. 1269-1 and 1517 (Fig. 3). The two latter strains shared $99.6 \%$ similarity. Despite the low statistical support, these four Y-branching strains were always associated together and separated from the T-branching clusters (clusters 1, 2, 3) in all analyses. The sequences of cluster 5 were equally distant (93\% sequence similarity) with the sequences of the nostocalean strain Scytonema hofmanni PCC 7110 and those of cluster 1. Moreover, according to the traditional classification system (Anagnostidis \& Komárek, 1990), Mastigocladopsis repens would be classified into the family Nostochopsaceae based on the presence of lateral-pedicellate heterocysts, such as found in the Nostochopsis strains of cluster 1. The divergence between the Nostochopsis and Mastigocladopsis strains suggests that the lateral-pedicellate heterocysts are of rather low taxonomic significance. 


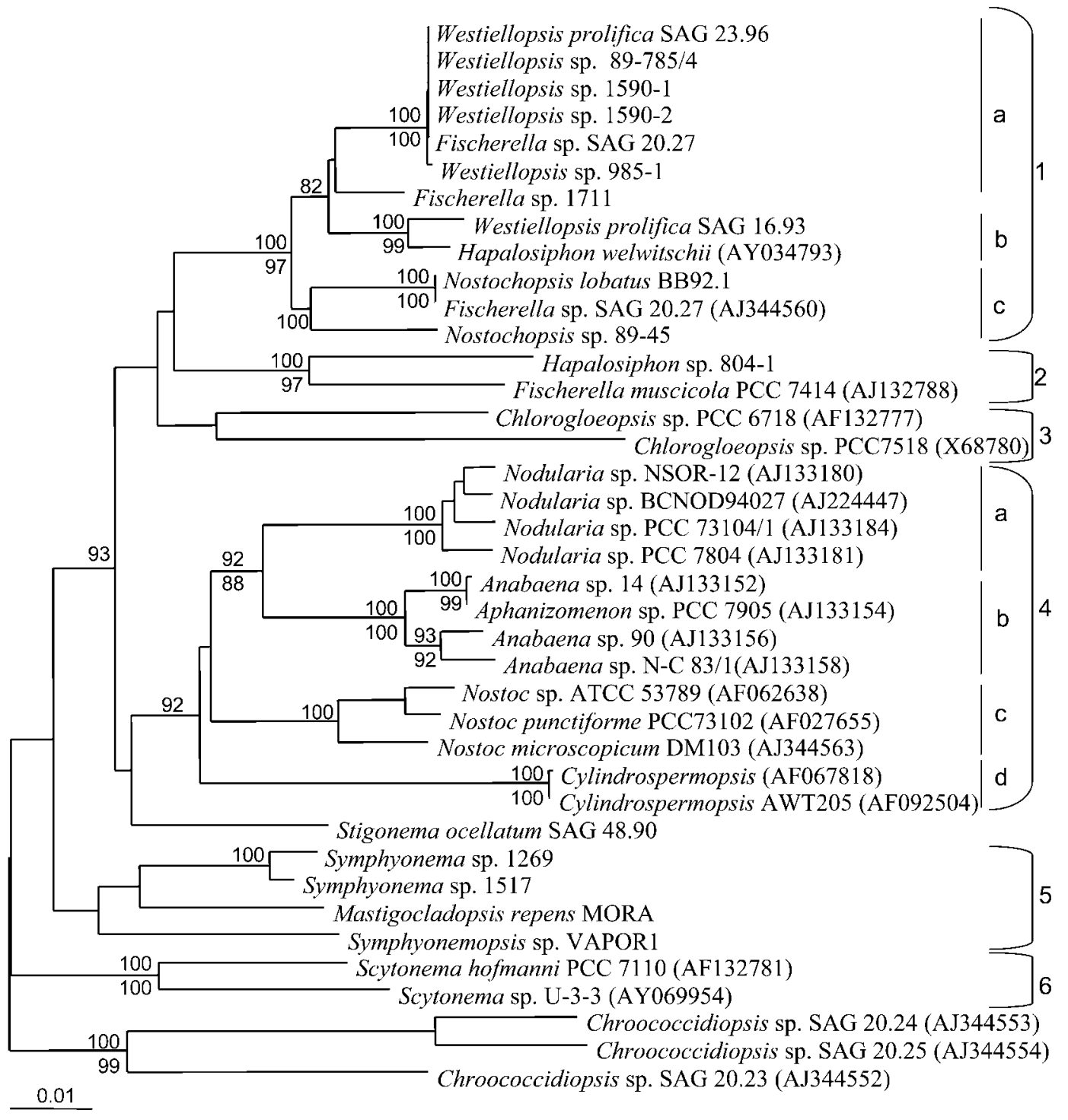

Fig. 3. Phylogenetic relationships of heterocystous filamentous isolates belonging to the orders Nostocales and Stigonematales based on 16S rDNA sequences (1239-1296 bp). The tree was inferred using the neighbour-joining method based on Jukes \& Cantor (1969) distances. Bootstrap values greater than $80 \%$ with distance/parsimony methods are indicated on the tree. Sequences from GenBank are indicated by accession numbers. The main clades are indicated by numbers.

The genus Stigonema is the type genus of the order Stigonematales. However, the 16S rDNA sequence of Stigonema ocellatum SAG 48.90 shared less than $95 \%$ similarity with the sequences of the other stigonematalean strains and had an ambiguous position, being equally distant from the T- and Y-clusters (Fig. 3). As Stigonema SAG 48.90 was the only example of multiseriate filaments with T-branching among our isolates, no conclusions can be drawn on this morphotype.

The group of Nostocales strains (Subsection IV) was also polyphyletic and separated into two clusters (4 and 6 in Fig. 3). Cluster 4 contained the non-branched heterocystous cyanobacteria distributed in four distinct subclusters, 4a4d, containing, respectively, Nodularia, AnabaenalAphanizomenon, Nostoc and Cylindrospermopsis. The sequence similarity within each of these clusters exceeded $97 \cdot 5 \%$. Cluster 6 contained the false-branching Scytonema strains, which shared only $95 \cdot 2 \%$ sequence similarity. This cluster was always basal in the phylogenetic analyses of heterocystous cyanobacteria.

\section{Taxonomy of heterocystous cyanobacteria}

Representatives of Subsections IV (Nostocales) and V (Stigonematales), currently circumscribed on the basis of 
the presence or absence of true branching, were intermixed in all our phylogenetic inferences. Subsequently, the traditional distinction of each Subsection (Desikachary, 1959; Rippka et al., 1979; Bourrelly, 1985; Komárek \& Anagnostidis, 1989; Anagnostidis \& Komárek, 1990; Castenholz, 2001) was not supported by this study.

The phylogenetic analyses of our dataset supported the monophyletic lineage of heterocyst-forming cyanobacteria as described previously on the basis of $16 \mathrm{~S}$ rDNA sequences (Giovannoni et al., 1988; Turner, 1997; Wilmotte \& Herdman, 2001; Fewer et al., 2002; Litvaitis, 2002) as well as nifH gene sequences (Zehr et al., 1997). This implies that, unlike the filamentous non-heterocystous or unicellular morphotypes, all the cyanobacteria with heterocysts studied so far evolved from a common ancestor. Consequently, a single Subsection formed of the actual Nostocales and Stigonematales members, and united upon the synapomorphic character of the heterocyst would better fit their monophyly and be in agreement with the Heterocysteae described by Bornet \& Flahault (1886).

Several monophyletic groups, such as Prochlorococcus/ marine Synechococcus (Urbach et al., 1998; Rocap et al., 2002), Euhalothece (Garcia-Pichel et al., 1998) and Planktothrix (Suda et al., 2002), were recently revealed and correlated with ecological and/or physiological characteristics. Within the heterocystous cyanobacteria, only morphological features seem so far to be used to delineate the main monophyletic assemblages. The combination of presence or absence of branching and branching type may represent an important diacritical character for defining monophyletic lineages. Thus, clusters 1, 4, 5 and 6 can be defined as containing, respectively, genera with true branching of the T-type, without branching, with true branching of the Y-type and with false-branching. Furthermore, a great similarity is observed in the ontogeny of false- and Y-branching, as in both types the development of a branch is associated with the activation of an intercalary meristem. Y-branching, as well as geminate falsebranching, are frequently observed in at least some strains of cluster 5 (especially in the Symphyonema strains). Moreover, the sequence of Symphyonemopsis sp. VAPOR1 was as distant from the other Y-branching strains as from the false-branching Scytonema hofmanni PCC 7110. New isolates are needed to study further the possible evolution of the Y-branching cyanobacteria from false-branching heterocystous cyanobacteria.

In conclusion, the 16 new stigonematalean $16 \mathrm{~S}$ rDNA sequences presented in this study demonstrated that the true branching cyanobacteria are polyphyletic and can be separated into at least two major groups that are well defined by their branching types. So far, only 9 out of the 48 true branching cyanobacterial genera (Anagnostidis \& Komárek, 1990) are represented in the 16S rRNA gene tree. Several morphotypes, especially pseudoparenchymatous taxa (e.g. Pulvinularia) or dichotomous branching taxa (e.g. Loriella), as well as representative taxa of the
Borzinemataceae and the Capsosiraceae, are lacking in cultures and in phylogenetic analyses. Furthermore, it remains to be investigated whether non-heterocystous true branching cyanobacteria (such as Doliocatella, Geitleria and Umezakia) originated from filamentous non-heterocystous cyanobacteria or from the heterocystous cyanobacteria.

\section{ACKNOWLEDGEMENTS}

We thank Dietmar Hoffmann for the use of the sequences corresponding to Scytonema sp. U-3-3 and Hapalosiphon welwitschii, B. Büdel and M. Hernandez-Mariné for providing respectively Nostochopsis lobatus BB92.1 and Mastigocladopsis repens, and Maria Laamanen for her critical reading of the manuscript. The financial support of the Belgian National Fund for Scientific Research to L.H. is greatly acknowledged for sampling in Papua New Guinea.

\section{REFERENCES}

Anagnostidis, K. \& Komárek, J. (1990). Modern approach to the classification system of Cyanophytes 5 - Stigonematales. Arch Hydrobiol Suppl 86, 1-73.

Bornet, E. \& Flahault, C. (1886). Révision des Nostocacées filamenteuses hétérocystées contenues dans les principaux herbiers de France. Ann Sci Nat Bot Ser 3 7, 323-381.

Bourrelly, P. (1985). Les Algues d'Eau Douce. III Eugléniens, Péridiniens, Algues Rouges et Algues Bleues, 2nd edn. Paris: N. Boubée \& Cie.

Castenholz, R. W. (1969). The thermophilic cyanophytes of Iceland and the upper temperature limit. J Phycol 5, 360-368.

Castenholz, R. W. (1978). The biogeography of hot spring algae through enrichment cultures. Mitt Int Verein Limnol 21, 296-315.

Castenholz, R. W. (2001). General characteristics of the cyanobacteria. In Bergey's Manual of Systematic Bacteriology, 2nd edn, vol. 1, pp. 474-487. Edited by D. R. Boone \& R. W. Castenholz. New York: Springer.

Desikachary, T. V. (1959). Cyanophyta. ICAR Monographs on Algae. New Dehli: Indian Council of Agricultural Research.

Felsenstein, J. (1993). PHYLIP (phylogeny inference package), version 3.5c. Seattle: Department of Genetics, University of Washington.

Fewer, D., Friedl, T. \& Büdel, B. (2002). Chroococcidiopsis and heterocyst-differentiating cyanobacteria are each other's closest living relatives. Mol Phylogenet Evol 23, 82-90.

Garcia-Pichel, F., Nübel, U. \& Muyzer, G. (1998). The phylogeny of unicellular, extremely halotolerant cyanobacteria. Arch Microbiol 169, 469-482.

Giovannoni, S. F., Turner, S., Olsen, G., Barns, S., Lane, D. J. \& Pace, N. R. (1988). Evolutionary relationships among Cyanobacteria and green chloroplasts. J Bacteriol 170, 3584-3592.

Golubíc, S., Hernandez-Mariné, M. \& Hoffmann, L. (1996). Developmental aspects of branching in filamentous Cyanophyta/ Cyanobacteria. Arch Hydrobiol Suppl 117, 303-329.

Gugger, M., Lyra, C., Henriksen, P., Couté, A., Humbert, J.-F. \& Sivonen, S. (2002). Phylogenetic comparison of the cyanobacterial genera Anabaena and Aphanizomenon. Int J Syst Evol Microbiol 52, 1867-1880.

Herdman, M., Janvier, M., Rippka, R. \& Stanier, R. Y. (1979a). Genome size of cyanobacteria. J Gen Microbiol 111, 73-85.

Herdman, M., Janvier, M., Waterbury, J. B., Rippka, R., Stanier, R. Y. \& Mandel, M. (1979b). Deoxyribonucleic acid base composition of cyanobacteria. J Gen Microbiol 111, 63-71. 
Hernandez-Mariné, M. C., Fernández, M. \& Merino, V. (1992) Mastigocladopsis repens (Nostochopsaceae): a new cyanophyte from Spanish soils. Cryptogam Algol 13, 113-120.

Hoffmann, L. (1990). Presence of Mastigocladopsis jogensis (Cyanophyceae, Mastigocladopsidaceae) in Corsica (France). Cryptogam Algol 11, 219-224.

Hoffmann, L. (1994). Characterization of Mastigocladospis jogensis (Cyanophyceae, Stigonematales) in culture. Arch Hydrobiol Suppl 103, 43-55.

Hoffmann, L. \& Castenholz, R. W. (2001). Subsection V (formerly Stigonematales Geitler 1925). In Bergey's Manual of Systematic Bacteriology, 2nd edn, vol. 1, pp. 589-599. Edited by D. R. Boone \& R. W. Castenholz. New York: Springer.

Hoffmann, L., Gugger, M. \& Asencio-Martinez, A. D. (2003). Morphological and molecular characterization of a stigonematalean cyanobacterium isolated from a Spanish cave. Arch Hydrobiol Suppl 148, 259-266.

Iteman, I., Rippka, R., Tandeau de Marsac, N. \& Herdman, M. (2002). rDNA analyses of planktonic heterocystous cyanobacteria, including members of the genera Anabaenopsis and Cyanospira. Microbiology 148, 481-496.

Jeeji-Bai, N. (1972). The genus Westiellopsis Janet. In Taxonomy and Biology of Blue-Green Algae, pp. 62-74. Edited by T. V. Desikachary. Madras: University of Madras.

Jukes, T. H. \& Cantor, C. R. (1969). Evolution of protein molecules. In Mammalian Protein Metabolism, pp. 21-132. Edited by H. N. Munro. New York: Academic Press.

Komárek, J. \& Anagnostidis, K. (1989). Modern approach to the classification system of Cyanophytes 4 - Nostocales. Arch Hydrobiol Suppl 82, 247-345.

Kotai, J. (1972). Instructions for Preparation of Modified Nutrient Solution Z8 for Algae, Publication B-11/69. Blindern, Oslo: Norwegian Institute for Water Research.

Lachance, M.-A. (1981). Genetic relatedness of heterocystous cyanobacteria by deoxyribonucleic acid-deoxyribonucleic acid reassociation. Int J Syst Bacteriol 31, 139-147.

Lane, D. J. (1991). 16S/23S sequencing. In Nucleic Acid Techniques in Bacterial Systematics, pp. 115-174. Edited by E. Stackebrandt \& M. Goodfellow. Chichester: Wiley.

Litvaitis, M. K. (2002). A molecular test of cyanobacterial phylogeny: inferences from constraint analyses. Hydrobiologia 468, 135-145.

Ludwig, W., Strunk, O., Klugbauer, S., Weizenegger, M., Neumaier, J., Bachleitner, M. \& Schleifer, K. H. (1998). Bacterial phylogeny based on comparative sequence analysis. Electrophoresis 19, 554-568.

Lyra, C., Suomalainen, S., Gugger, M., Vézie, C., Sundman, P., Paulin, L. \& Sivonen, K. (2001). Molecular characterization of planktic cyanobacteria of Anabaena, Aphanizomenon, Microcystis and Planktothrix genera. Int J Syst Evol Microbiol 51, 513-526.

Merino, V., Hernández-Mariné, M. \& Fernández, M. (1994). Ultrastructure of Mastigocladopsis repens (Stigonematales, Cyanophyceae). Cryptogam Algol 15, 37-46.
Otsuka, S., Suda, S., Li, R., Watanabe, M., Oyaizu, H., Matsumoto, S. \& Watanabe, M. M. (1998). 16S rDNA sequences and phylogenetic analyses of Microcystis strains with and without phycoerythrin. FEMS Microbiol Lett 164, 119-124.

Page, R. D. M. (1996). TREEVIEW: an application to display phylogenetic trees on personal computers. Comput Appl Biosci 12, 357-358.

Rippka, R., Deruelles, J., Waterbury, J. B., Herdman, M. \& Stanier, R. Y. (1979). Generic assignments, strain histories and properties of pure cultures of cyanobacteria. J Gen Microbiol 111, 1-61.

Rocap, G., Listel, D. L., Waterbury, J. B. \& Chisholm, S. W. (2002). Resolution of Prochlorococcus and Synechococcus ecotypes by using 16S-23S ribosomal DNA internal transcribed spacer sequences. Appl Environ Microbiol 68, 1180-1191.

Stackebrandt, E. \& Goebel, B. M. (1994). Taxonomic note: a place for DNA-DNA reassociation and 16S rRNA sequence analysis in the present species definition in bacteriology. Int J Syst Bacteriol 44, 846-849.

Suda, S., Watanabe, M. M., Otsuka, S., Mahakahant, A., Yongmanitchai, W., Nopartnaraporn, N., Liu, Y. \& Day, J. G. (2002). Taxonomic revision of water-bloom-forming species of oscillatorioid cyanobacteria. Int J Syst Evol Microbiol 52, 1577-1595.

Turner, S. (1997). Molecular systematics of oxygenic photosynthetic bacteria. Plant Syst Evol 11, 13-52.

Turner, S., Pryer, K. M., Miao, V. P. W. \& Palmer, J. D. (1999). Investigating deep phylogenetic relationships among cyanobacteria and plastids by small subunit rRNA sequence analysis. Eukaryot Microbiol 46, 327-338.

Urbach, E., Scanlan, D. J., Distel, D. L., Waterbury, J. B. \& Chisholm, S. W. (1998). Rapid diversification of marine picoplankton with dissimilar light-harvesting structures inferred from sequences of Prochlorococcus and Synechococcus (Cyanobacteria). J Mol Evol 46, 188-201.

Weber, B., Wessels, D. C. J. \& Büdel, B. (1996). Biology and ecology of cryptoendolithic cyanobacteria of a sandstone outcrop in the Northern Province, South Africa. Algol Stud 83, 565-579.

Wilmotte, A. (1994). Molecular evolution and taxonomy of the cyanobacteria. In The Molecular Biology of Cyanobacteria, pp. 1-25. Edited by D. A. Bryant. Dordrecht: Kluwer.

Wilmotte, A. \& Herdman, M. (2001). Phylogenetic relationships among the cyanobacteria based on $16 \mathrm{~S}$ rRNA sequences. In Bergey's Manual of Systematic Bacteriology, 2nd edn, vol. 1, pp. 487-493. Edited by D. R. Boone \& R. W. Castenholz. New York: Springer.

Wilmotte, A., van der Auwera, A. G. \& de Watcher, R. (1993). Structure of the $16 \mathrm{~S}$ ribosomal RNA of the thermophilic cyanobacterium Chlorogloeopsis HTF ('Mastigocladus laminosus HTF') strain PCC 7518, and phylogenetic analysis. FEBS Lett 317, 96-100.

Zehr, J. P., Mellon, M. T. \& Hiorns, W. D. (1997). Phylogeny of cyanobacterial nifH genes: evolutionary implications and potential applications to natural assemblages. Microbiology 143, 1443-1450. 